\title{
IMPLEMENTING OF POLYTECHNIC STUDENTS' ABILITY OF WRITING APPLICATION LETTERS
}

\author{
Masrul Huda ${ }^{1}$ Gozali $^{2}$ \\ Jl Sukarno Hatta, State Polytechnic of Balikpapan. Balikpapan Utara, \\ Kalimantan Timur, Indonesia \\ masrul.huda@poltekba.ac.id ${ }^{l}$, gozali@poltekba.ac.id ${ }^{2}$
}

\begin{abstract}
Writing an English application letter is one of 'Job Getting' materials. The writing results can measure the students' writing ability in English. This study aims to describe the writing quality of English application letters made by State Polytechnic of Balikpapan students. It also tries to explain frequent errors in the application letter. The research method used is descriptive qualitative. The data obtained were assessed based on a scoring rubric. There are four criteria assessed including content, organization, grammar, and mechanic. The data results are presented in the tables, graphs, and description. The results show (1) Most of the students' abilities are at Scale 4 and none has the ability at Scale 1. The average number of each component is Content 3,95; Organization 3,89; Grammar 3,38; and Mechanic 3,30. (2) Errors made in writing application letters can be found in all components. Most mistakes were made by students in all components, respectively, mechanics, grammar, organization, and content.
\end{abstract}

Keywords: Error Analysis, Job Application Letter, Writing Ability.

\begin{abstract}
ABSTRAK
Menulis surat lamaran pekerjaan dalam Bahasa Inggris menjadi salah satu materi di Materi 'Job Getting'. Hasil tulisan tersebut dapat mengukur kemampuan menulis mahasiswa dalam Bahasa Inggris. Penelitian ini bertujuan untuk mendeskripsikan kualitas surat lamaran pekerjaan yang dibuat oleh mahasiswa Politeknik Negeri Balikpapan. Penelitian ini menjelaskan kesalahan dalam penulisan surat lamaran pekerjaan. Metode penelitian yang dilakukan adalah deskriptif kualitatif. Data yang diperoleh dinilai berdasarkan rubrik penilaian. Terdapat empat kriteria yang dinilai meliputi content, organization, grammar, dan mechanic. Hasil dari analisis data dipaparkan dalam bentuk tabel, grafik dan pemaparan secara deskriptif. Hasil analisis menunjukkan bahwa (1) Kemampuan mahasiswa sebagian besar di Skala 4 dan tidak ada satupun yang mempunyai kemampuan di Skala 1. Angka ratarata tiap komponen adalah Content 3,95; Organization 3,89; Grammar 3,38; dan Mechanic 3,30 (2) Kesalahan yang dilakukan dalam penulisan surat lamaran terdapat di semua komponen. Kesalahan terbanyak dilakukan mahasiswa pada komponen berturut-turut mechanic, grammar, organization dan content.
\end{abstract}

Kata Kunci: Analisis Kesalahan, Surat Lamaran Pekerjaan, Kemampuan Menulis.

\section{INTRODUCTION}

State Polytechnic of Balikpapan is a vocational college having the vision to produce graduates with global competitiveness. The polytechnic is required to equip its graduates with qualified foreign language skills. Various attempts have been made. One of them is by designing a curriculum to produce work-ready graduates. The English curriculum at State Polytechnic of Balikpapan is divided into several parts, such as reading, speaking, writing and job getting. Job getting material is given to all 
Sixth-semester students. It is intended its students will be ready to enter the work world. It means the polytechnic does not only equip graduates with engineering skills but also language skill.

Nowadays, many companies require their job applicants to write an application letter in English. It is done to determine the job applicants' initial ability to express their ideas in English. Based on the explanation above, the researchers need to know the State Polytechnic of Balikpapan students' mastery in English writing. The research can be used as a basis for English lecturers to maximize their teaching method and the material. It is expected that the researchers can find the appropriate strategy given to students to improve their English language skills, especially writing. Based on the background of the study, the researchers came up with the following problems: how is the ability of State Polytechnic of Balikpapan students in writing an English job application letters?, and what are writing errors made during producing an English job application letter?

\section{LITERATURE REVIEW}

\section{Application letter}

In English, the term of the job application letter is also known as a cover letter. A job application letter is intended to provide detailed information along with the reasons why the prospective worker becomes a candidate who meets the requirements for the job vacancy offered. The job application letter is usually sent along with a resume functioning as an additional information document about the applicant's skill and experience (Doyle, 2019). Doyle (2019) states the ideal job application letter includes three parts:

1. Introduction. This section covers where a job applicant gets information about the job vacancy, the position applied for and the reasons why an applicant is interested to apply for a job.

2. Body. This section describes the qualifications possessed by a job applicant. It contains certain abilities or skills required in carrying out the work applied. It usually highlights the main reasons why an applicant is worthy.

3. Closing. This section contains gratitude and appreciation to the job recipient for taking the time to read and consider an applicant's letter. It serves a piece of information for the recipient to contact a job applicant as a follow-up in the recruitment process. It is usually completed with the applicant's signature and full name.

\section{Writing Assessment}

According to Nurgiyantoro (2001), writing is a productive activity to 
produce language. In general, writing is an activity to express ideas through language media. It can be concluded that an important element of writing is the element of language and its ideas. The writing competency assessment considers the elements of language and ideas, so the appropriate writing assignment is an essay in the text form. According to Nurgiyantoro (2001), the writing assessment types are: arranging paragraphs: objective tests, writing based on visual stimuli, writing based on sound stimuli, writing based on book stimuli, writing reports, writing letters, and writing based on certain topics.

\section{Error Analysis (EA)}

Dulay, Burt and Krashen (1982) state Error Analysis (EA) is a method for analysing errors made by EFL (English Foreign Learner) when they learn a language. The method helps to reveal further strategies based on the studies conducted. The method helps teachers determine better teaching materials to improve the language learner ability because it reveals the difficulties faced by learners in receiving learning. James (1998) explains error analysis is an analysis of the learners' mistakes by comparing what learners learned to what they have. Crystal (1999) adds Error Analysis (EA) is a language study in which language learners make mistakes from the target language being learned.

\section{Classification of Errors}

Dulay, Burt, and Krashen (1982) categorize errors into six different categories: omission of grammatical morphemes, double signs of semantic features, irregular use of rules, use of wrong tenses, alternating use of two or more forms, and wrong use. James (1998) proposes five categories of errors including grammatical errors (adjectives, adverbs, articles, nouns, possessions, pronouns, prepositions, and verbs), substance errors (capitalization, punctuation and spelling), lexical errors (word formation and word selection), syntactic errors (coordination/subordination, sentence structure and ordering), and semantic errors (ambiguous communication and miscommunication)

\section{RESEARCH METHOD}

\section{Types of Research Method}

(Lambert V. \& Lambert C, 2012) state qualitative descriptive method is the most theoretical of all approaches to qualitative research. (Nassaji, 2015) explains the method objective is to describe the phenomenon and its characteristics. Qualitative research is more holistic because it involves data from multiple sources to gain a 
deeper understanding from an individual including perspectives and attitudes.

This research was conducted using a qualitative-descriptive method because it focuses on the analysis obtained from the Sixth-semester student assignments who are taking a Job Getting course. In short, the researchers analysed based on the data obtained and explained in descriptive form. The data are obtained from 63 students' results in writing English job application letters. The students took English 3: Job Getting course. The data analysis was begun by collecting 63 assignments to write an English job application letter. Scenarios for data analysis techniques are as follows: Collecting data: the data is retrieved through writing assignments. After the data is collected, the results are printed using a writing rubric. Classifying or identifying errors: the researcher identifies what types of errors students made in grammar and vocabulary used. Data were analysed based on Content, Organization, Grammar, and Mechanics using a scoring rubric adapted from Cohen (1994).

\begin{tabular}{|c|c|l|}
\hline $\begin{array}{c}\text { Component } \\
\text { of writing }\end{array}$ & Scale & \multicolumn{1}{|c|}{ Indicator } \\
\hline Content & 5 & $\begin{array}{l}\text { Main ideas are stated clearly and accurately } \\
\text { Main ideas are stated fairly, clearly, and accurately } \\
\text { Main ideas are stated somewhat unclear or } \\
\text { inaccurate }\end{array}$ \\
& 3 & Main ideas are stated not clear or accurate \\
& 2 & Main ideas are stated not all clear or accurate \\
\hline Organization & 5 & Well organized and perfectly coherent \\
& 4 & Fairly well organized and generally coherent \\
& 3 & Loosely organized but main ideas clear, logical, but \\
incomplete sequencing \\
& 1 & Ideas disconnected and lacks logical sequencing \\
& & No organization, incoherent \\
\hline Grammar & 5 & No errors, full control of the complex structure \\
& 4 & Almost no errors, good control of the structure \\
& 3 & Some errors, fair control of the structure \\
& 2 & Many errors, poor control of the structure \\
& 1 & Dominated by errors, no control of the structure \\
\hline Mechanic & 5 & Mastery of spelling \\
& 4 & Few errors in spelling and punctuation \\
& 3 & Fair number of spelling and punctuation errors \\
& 2 & Frequent errors in spelling and punctuation \\
& 1 & No control over spelling and punctuation \\
\hline
\end{tabular}

Table 1. Writing Assessment Rubric adapted from Cohen (1994)

How to calculate the value:

1. Job application letters are assessed based on a specified scale 
2. The number of scores obtained from 4 components (Content, Organization, Grammar, and Mechanic)

3. The result is the average of each component

The next step is to describe the results of the assessment in the form of content errors, organizational errors, grammar errors, and mechanical errors.

\section{FINDINGS AND DISCUSSION}

\section{FINDINGS}

The section describes the distribution results of the five predefined scales. The results of data analysis are presented in tables and graphs. The tables are used as distribution recapitulation of 63 written results obtained from the research samples. The graphs are used as an illustration from recapitulation results. There are four writing components which are analysed, namely (1) Content, (2) Organization, (3) Grammar and (4) Mechanic.

\section{Content}

In this component, an assessment is carried out by looking at the main idea of each paragraph including opening, body, and closing. The results are distributed in the table below:

Table 2. The recapitulation of 'Content' assessment

\begin{tabular}{|c|c|}
\hline Scale & Total \\
\hline 5 & 16 \\
\hline 4 & 30 \\
\hline 3 & 15 \\
\hline 2 & 2 \\
\hline 1 & 0 \\
\hline
\end{tabular}

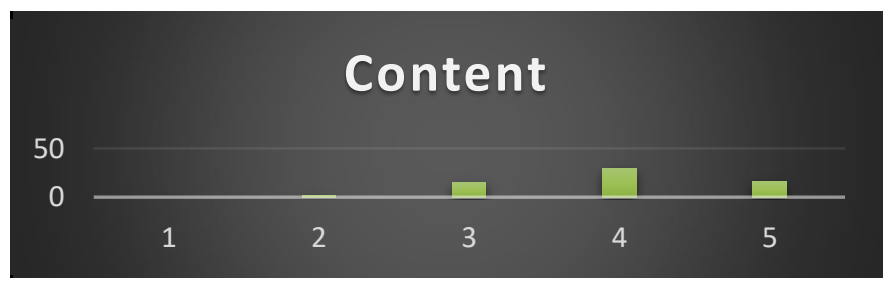

Graph 1. The results of the 'Content' assessment

\section{Organization}


The assessment made on this component includes coherence between paragraphs and regularity in producing a paragraph that is interrelated and related. The results are distributed in the table below:

Table 3. The recapitulation of 'Organization' assessment

\begin{tabular}{|c|c|}
\hline Scale & Total \\
\hline 5 & 13 \\
\hline 4 & 33 \\
\hline 3 & 14 \\
\hline 2 & 3 \\
\hline 1 & 0 \\
\hline
\end{tabular}

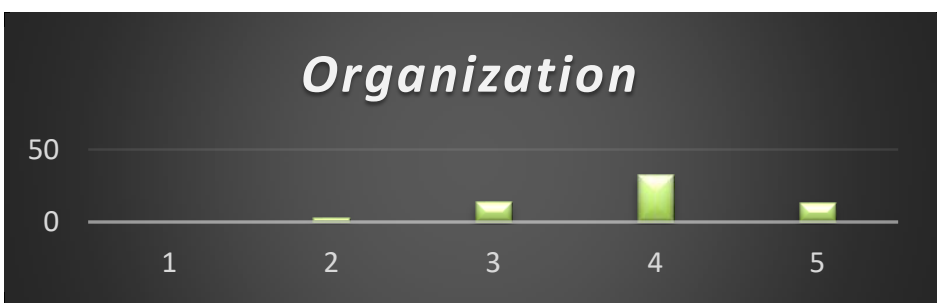

Graph 2. The results of 'Organization' assessment

\section{Grammar}

This component is crucial because in English, grammar functions as grammar and becomes an internal component affecting the coherence and sequence between paragraphs. Grammar components can cause other components to have no connection if the grammar is used incorrectly. The results are distributed in the table below:

Table 4. The recapitulation of 'Grammar' assessment

\begin{tabular}{|c|c|}
\hline Scale & Total \\
\hline 5 & 1 \\
\hline 4 & 31 \\
\hline 3 & 22 \\
\hline 2 & 9 \\
\hline 1 & 0 \\
\hline
\end{tabular}

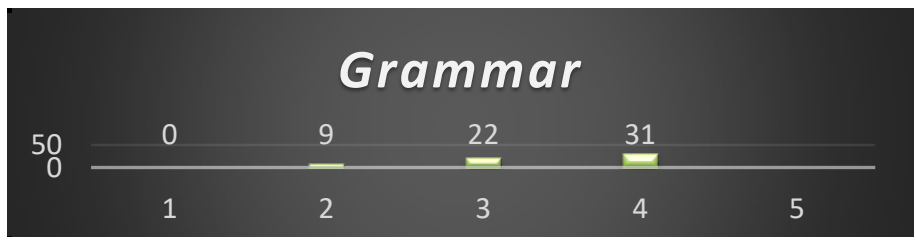

Graph 3. The results of 'Grammar' assessment 


\section{Mechanic}

This component acts as a supporting factor for the neatness of a written result. There are two important things used as a benchmark in determining the scale: spelling, punctuation, and capitalization. The results are distributed in the table below:

Table 5. The recapitulation of 'Mechanic' assessment

\begin{tabular}{|c|c|}
\hline Scale & Total \\
\hline 5 & 1 \\
\hline 4 & 31 \\
\hline 3 & 17 \\
\hline 2 & 14 \\
\hline 1 & 0 \\
\hline
\end{tabular}

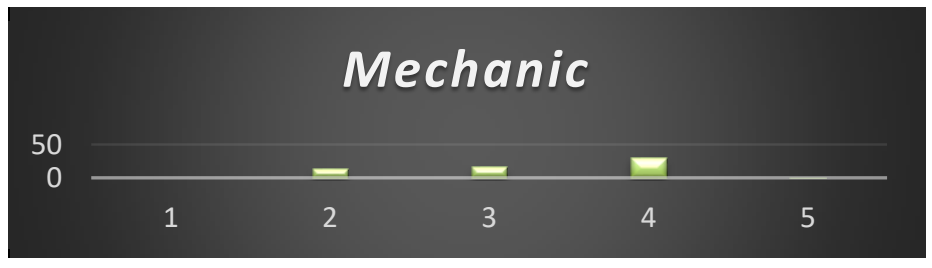

Graph 4. The results of 'Mechanic' assessment

\section{DISCUSSION}

This section describes the description of the errors obtained from the 63-job application letters assessed.

\section{Content}

Analysis of this component is carried out by looking at the main idea of each paragraph including opening, body, and closing.

Opening. The analysis is carried out by looking at the completeness of items such as job application source information which includes the website/company address and the time the company advertises job vacancies, the position the applicant wishes to apply for, and the applicant's interest in the position. The results showed that students can apply the use of salutation which is useful as an opening greeting. In this section, students can also write about sources of job applications obtained both online and offline. The results showed that students can apply the idea in the opening. In practice, the positions listed in job application letters are customer service, teller, 
back office, and finance.

Body. In this section, an analysis is carried out on the student's ability to reveal the qualifications and reasons the applicant deserves to be considered along with the experience possessed by the applicant. In this section, students share a lot of experiences and knowledge gained during the OJT (on the job training) program at banks and pawnshops. Students also tell about the skills they have and the application of these skills in the world of work.

Closing. The ability of students in writing the closing section shows various abilities. The use of several sentences used as gratitude to readers of job applications for the time given and the hope of the applicant to be called back is very satisfying.

\section{Organization}

The analysis carried out in this section includes the student's ability to make coherent writing between paragraphs. This coherence is seen by linking the continuity between paragraphs. In general, students have succeeded in making coherent paragraphs because students already understand the parts of each paragraph and can use conjunctions that are useful to form writing into a unified whole.

\section{Grammar}

The results of the analysis show that several mistakes were made by students in making job application letters.

\section{Modal}

The error occurs in the usage of the verb after the modal. The expected verb is the infinitive $\left(\mathrm{V}_{1}\right)$, but in practice, there are several verbs in the Ving, $\mathrm{V}_{2}, \mathrm{~V}_{3}$ and to infinitive forms.

Example:

(1) I can reached at

(2) I can operateing

(3) ... will freely see my CV or te contact ...

\section{Tenses}

The mismatch between the subject and the verb is a frequent occurrence. This error becomes quite crucial because the form of the verb can affect the timing of a particular event. The form of tense that is often wrong is the Present Perfect Tense. The verb after have / has, which should be a past participle $\left(V_{3}\right)$, is instead in $V_{1}, V$-s and $\mathrm{V}_{2}$. 
Example:

(1) My financial strength includes ....

(2) ... background has provides $\underline{\mathbf{d}}$...

(3) I have graduated ...

(4) I have completes $\underline{\mathbf{d}}$

\section{Tobe}

In nominal sentences, to be (is, am, are, was were) is used as an auxiliary verb. This is because all sentences in English must have a verb. The absence of tobe often occurs in nominal sentences that include an adjective (adjective) and a noun (noun) after the subject.

Example:
(1) I am confident
(2) ... there is a job
(3) I am eager

\section{Prepositions}

There are many mis conformances between words using prepositions such as at, on, in, etc. Students are less able to see the function and use of each preposition used.

Example:

(1) I graduated at from Polytechnic ...

(2) ....after graduating of from ...

\section{Mechanic}

Items that are taken into consideration in granting this component are spelling, punctuation and capitalization.

Spelling. Errors occur in the writing of spelling, including spelling that has not been translated into English, the addition of letters both vowels and consonants in words, missing letters, both vowels and consonants, and inverted letter positions.

Example:

(1) ... PolytechnicNegeri State Polytechnic - Not translated

(2) I alase also writing - Addition of letters

(3) 3 months trainingas training - Addition of letters

(4) I can eplain explain - Missing consonant letter 
(5) ...details rgreding regarding- Missing vowel letter

Punctuation. The use of punctuation marks that indicate multiple errors is a period and a comma.

Example:

(1) Mr.AlfizarBaihaqi - Mr. Alfizar Baihaqi - Missing space

(2) ... eompany.Previous ... company. Previous ... - Missing space

(3) ... staff position,considering ...- Missing space

(4) Dear Aditya (,) - No comma after name

Capitalization. This item is an additional item used to analyses Mechanic components. The analysis results show that the use of capital letters is often used to pronounce me 'I' which should be capital but written in small letter.

Example:

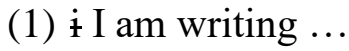

(2) after $\dot{+}$ I graduated

(3) bBalikapapan sState pPolytechnic

(4) ... curriculum vitae Wwhich shows ...

(5) I am writing to Ұyou

\section{CONCLUSION}

The study concludes (1) the analysis result of 4 components (content, organization, grammar, and mechanics), most of the students' abilities were on Scale 4 and none of them had the ability on Scale 1 . The average score for each component is Content 3, 95; Organization 3, 89; Grammar 3, 38; and Mechanic 3, 30. (2) Errors made in writing a cover letter can be found in all components. Most mistakes were made by students in the components, respectively, mechanics, grammar, organization, and content.

\section{BIBLIOGRAPHY}

Ary, D., Jacobs, L.C. Razavieh, A. (2002). Introduction to Research in Education, $6^{\text {th }}$ ed. New York: Wadsworth/Thomson Learning.

Axelrod, Rise. B. \& Charles R.C. (1985). The St. Martins' Guide to Writing. New York: St. Martin's Press

Brown, H. D. (2004). Language Assessment: Principles and Classroom Practices. New York: Addison Wesley Longman, Inc. 
Brown, H. D. (2007). Teaching by Principles: An Interactive Approach to Language Pedagogy. $3^{\text {rd }}$ ed. New York: Addison Wesley Longman, Inc.

Budiyono. (2003). Metodologi Penelitian. Surakarta: UNS Press.

Cohen, A. D. (1994). Assessing Language Ability in the Classroom. $2^{\text {nd }}$ ed. Boston: Heinle and Heinle Publishers.

Crystal, D. (1999). The Penguin Dictionary of Language. London: Penguin.

Dulay, H. C., Burt, M.K., \& Krashen, S.D. (1982). Language Two. New York: Oxford University Press

Doyle, Alison. 2019. Sample Cover Letter for a Job Application.

https://www.thebalancecareers.com/job-application-letter-sample-2062548 accessed April 8, 2020

Gebhard, J.G. (2000). Teaching English as a Foreign or Second Language: A Teacher Self-Development and Methodology Guide. Ann Arbor: The University of Michigan Press.

Glencoe. (2001). Writer's Choice: Grammar and Composition Grade 6. New York: McGraw-Hill Companies.

Hengwichitkul, L. (2006). An Analysis of Errors in English Abstracts Translated by Thai University Graduate Students. Srinakharinwirot University, Bangkok, Thailand.

James, C. (1998). Errors in Language Learning and Use: Exploring Error Analysis. New York: Routledge.

Lambert V, Lambert C. Qualitative Descriptive Research: An Acceptable Design. Pacific Rim International Journal of Nursing Research [Internet]. 16(4):255-6 Available from: https://www.tcithaijo.org/index.php/PRIJNR/article/view/5805

Lightbown, P. M. and Spada, Nina. (1999). How Languages are Learned. $2^{\text {nd }}$ ed.Oxford: University Press

Nassaji, H. (2015). Language Teaching Research: Qualitative and Descriptive Research: Data Type versus Data Analysis Vol. 19(2) 129-132. sagepub.co.uk/journalsPermissions.nav

Nurgiyantoro, Burhan. (2001). Penilaian dalam Pengajaran Bahasa dan Sastra. Yogyakarta : BPFE Yogyakarta

O'Malley, J. Michael and Pierce, L.V. (1996). Authentic Assessment for English Language Learners. New York: Addison-Wesley Publishing Company

Runkati, K. (2013). Organizational Patterns and Common Mistakes in English Research abstracts. Prince of Songkla University, Songkhla, Thailand. 
Sugiyono. (2008). Metode Penelitian, Pendekatan Kuantitatif, Kualitatif, dan R\&D. Alfabeta. Bandung.

Tarigan, Henry Guntur. Tarigan, Djago.(1995). Pengajaran Analisis Kesalahan Berbahasa. Bandung:Angkasa 